Tropical Journal of Pharmaceutical Research April 2010; 9 (2): 127-133

(C) Pharmacotherapy Group,

Faculty of Pharmacy, University of Benin,

Benin City, 300001 Nigeria.

All rights reserved.

Research Article

Available online at http://www.tjpr.org

\title{
Effect of Cedrus deodara (Pinaceae) Root Oil on the Histopathology of Rat Liver and Kidney
}

\author{
Rehana Parveen ${ }^{1}$, Muhammad A Azmi ${ }^{2^{*}}$, Syed Naeemul H \\ Naqvi ${ }^{1}$, Syed M Mahmood ${ }^{3}$ and ljaz $\mathrm{H}_{2}$ Zaidi $^{4}$ \\ 1 Department of Pharmacology, Institute of Pharmaceutical Sciences, '2 Department of Physiology, Baqai Medical \\ University, 51 Deh Tor, Gadap Road, Near Toll Plaza, Super Highway, P.O. Box 2407, Karachi-74600, ${ }^{3}$ Department \\ of Oncology, Agha Khan University Hospital, National Stadium Road, 'Department of Casualty, P.N.S. Shifa Hospital, \\ DHA, Phase 2, Karachi, Pakistan.
}

\begin{abstract}
Purpose: To evaluate the effect of Cedrus deodara (Pinaceae) root oil, used traditionally for the treatment of various ailments, on the histopathology of the liver and kidney of Wistar albino rats.

Methods: The oil was extracted from the plant root by dry destructive distillation method and administered orally at doses of $0.5 \mathrm{ml}$ and $2.5 \mathrm{ml}$ per rat. Each animal group was comprised of 30 rats. Treated and untreated group of rats were sacrificed and organs (liver and kidney) were taken out for tissue processing and staining with haematoxylin and eosin according to the method of Bancroft and Stevens. Microscopic examination was then carried out to observe any pathological changes in the animals.

Results: The root oil produced atrophic changes and haemolysis in the glomerular region as well as shrinkage and shedding of glomerular epithelium in the kidney tissues. Marked dilation of the central vein and congested blood vessels in the rat liver at both doses tested was also seen.

Conclusion: The root oil of $C$. deodara (Pinaceae), at the doses administered, produced some adverse effects on the tissues tested but these effects were not lethal. Some toxic changes in the tissues of liver and kidney were also found.
\end{abstract}

Keywords: Histopathology, Cedrus deodara root oil, Liver, Kidney, Albino rats. 


\section{INTRODUCTION}

Cedrus deodara (Deodar - Pinaceae) is found in the hilly areas of North Western Frontier Province (N.W.F.P.) of Pakistan and also in the Western Himalaya and the Mediterranean region. It is a tall evergreen tree with spreading horizontal branches having circular leaves. In the Indus-Unic system (previously Unani or Greek system), the plant's extracts, oils, etc, have been used in Eastern medicine for a long time in the treatment of patients for various ailments. For example, the wood extract is carminative, diaphoretic and antipyretic, and has also been used to treat flatulence, pulmonary and urinary disorders, rheumatism, piles and kidney stones. In addition, the bark extract is astringent and also useful for treating fever, diarrheoa and dysentery [1]. The root extract or oil,also contains terpenoids such as himachalol, atlantone and trans-atlantone; these are similar to those found in the trunk oil [2]. In the frontier province (N.W.F.P) of Pakistan, the root oil is used as an anti-ulcer drug by Hakims (old Unic-medical personals).

There is a report that one of the major component in the wood of Cedrus deodara, himachalol, has antispasmodic and spasmolytic activities similar to those of paparverine that also induces spasm in different tissues such as ileum, jejunum and bronchial muscles when given in different doses [3]. Another study reported the use of wood essential oil of Cedrus deodara, as a $15 \%$ dispersion in castor oil, as a dermal application in rabbit for the treatment of skin diseases [4]. Similarly, mast cell-stabilizing and lipoxygenase-inhibitory activities [5] as well as the immunological properties of Cedurs deodara oil in allergy caused by pollen antigens, have also been evaluated [6].

In vitro cytotoxic activity against human cancer cell lines, in vivo induction of intracellular caspases, DNA fragmentation and DNA cell cycle analysis have been reported [7-9]. Recently, a study investigated the lipid contents, specific surface areas and stomata density as well as the levels of accumulation of polycyclic aromatic hydrocarbons (PAHs) in two kinds of pine (Cedrus deodara and Pinus thunbergii) needles [10].

Considerable work has been done on the chemistry of stem bark in Pakistan and India to analyse stem bark extract or oil [11-14] but to the best of our knowledge, no scientific studies have been reported in the literature on the analysis of Cedrus deodara root oil and its pathological effects on animal tissues. Therefore, the objective of this study was to investigate the effect of Cedrus deodara root oil on the liver and kidney tissues of albino rats (Wistar Strain) at low and high dose levels.

\section{EXPERIMENTAL}

\section{Materials and animals}

The root oil of Cedrus deodara was collected from Brooke's Pharma (Pvt) Ltd, Karachi, Pakistan. The animals used for this experimental study were adult albino rats (Wistar strain), weighing $200 \pm 5 \mathrm{~g}$. They were housed in cages ( 2 rats per cage) in animal house and a well-balanced laboratory diet in the form of biscuits prepared in Hussain Ebrahim Jamal (HEJ) Research Institute of Chemistry, University of Karachi. The animals were kept in a $12 \mathrm{~h}$ light / $12 \mathrm{~h}$ dark cycle and water was given freely.

\section{Treatment protocol}

A total of 90 rats, divided into three groups (30 per group), were used. Group A rats (control) did not receive any treatment while Groups B and C were administered low (0.5 $\mathrm{ml} / \mathrm{rat})$ and high $(2.5 \mathrm{ml} / \mathrm{rat})$ doses of Cedrus deodara root oil orally by gauze syringe. All the animals were fasted overnight prior to being sacrificed. The animals were anaesthetized with chloroform, placed on a dissection board and their abdomen was opened via a long midline incision, the organs (liver and kidney) were taken out, blotted dry with tissue paper and then immediately 
transferred to normal saline for histopathalogical studies.

The approval for conducting the experimental procedures on the animals was given by Board of Advance Studies \& Research (BASR) and Ethics Committee of Baqai Medical University, Karachi - Pakistan with approval ref. no. BMU-VC/145.

\section{Routine tissue processing}

The tissues were fixed in normal saline for 24 - $48 \mathrm{~h}$ and then processed through a series of ethyl alcohol of ascending strength $(70,80$ and $95 \%$ ) for a period of $1 \mathrm{~h}$; twice in absolute alcohol (for $1 \mathrm{~h}$ each); and twice in xylene (for $1 \mathrm{~h}$ ) in order to render the tissue elements transparent. The tissues were then infiltrated with molten paraplast at $58{ }^{\circ} \mathrm{C}$. This was done twice (for one hour on each occasion). The transparent tissues, after clearing all elements from it, were embedded in a solid mass of paraplast. The blocks were labelled, allowed to cool and the metal blocks were removed. The solid mass was then trimmed free of excess paraplast, leaving some free margins around the embedded tissues.

Three microns thick longitudinal sections were cut with a rotary microtome. The sections were mounted on thoroughly cleaned gelatinized slides and the slides were then placed on hot plates at $37{ }^{\circ} \mathrm{C}$ for $24 \mathrm{~h}$ for proper fixation. The slides were stained by $H$ \& $E$ stain according to the prescribed staining method [15]. The stain was prepared by dissolving hematoxylin in absolute alcohol. The mixture was boiled rapidly and mercuric oxide was then added. The stain was cooled rapidly in a cold water bath; glacial acetic acid was then added and the stain was ready for immediate use. Several slides were prepared accordingly. The stained slides, after drying and labelling, were preserved and stored for histopathological studies which entailed microscopical examination for comparative morphological and pathological changes in the tissues of the animals.

\section{RESULTS}

The general characteristic features of the liver and kidney tissue sections of the animals examined microscopically are presented in Table 1.

\section{Liver changes in rats with root oil high dose}

Normal liver tissues were observed as normal central vein, sinusoids and hepatic cells in the control group (see Fig 1a). However, histopathological changes were seen in the liver tissues of albino rats treated with a high dose of Cedrus deodara root oil $(2.5 \mathrm{ml} / \mathrm{rat})$. The general architecture of liver tissue was found intact but fatty changes $(++)$ were seen (Figure 1b); almost intact portal vein and markedly dilated central vein were also seen (Figure 1c). Congested (+) blood vessels and necrotic and fibrotic changes were not seen. In addition, few inflammatory cells (+) were also found on examination.

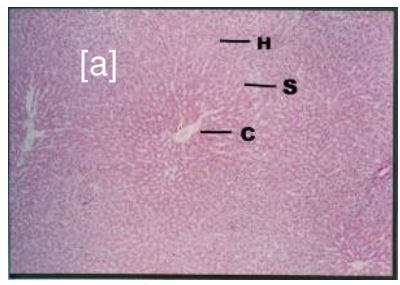

(a) Control liver

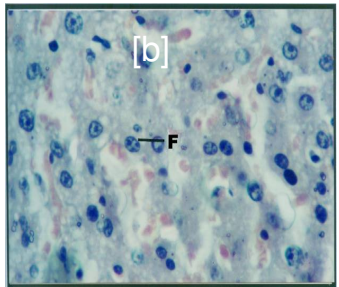

(b) Treated liver

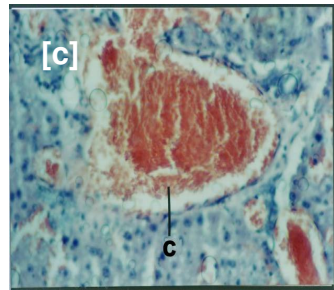

(c) Treated liver
Figure 1: Sections (a) of rat liver (Control) showing normal central vein $(C)$, sinusoid $(S)$ and hepatic cells $(H)$; (b) fatty changes $(F)$; and (c) dilated central vein (C), following treatment of rats with Cedrus deodara root oil $(2.5 \mathrm{ml})$ 
Parveen et al

Table 1: Gross features of untreated and treated liver and kidney tissues of albino rats.

\begin{tabular}{|c|c|c|c|}
\hline $\begin{array}{c}\text { Tissue } \\
\text { Type }\end{array}$ & Control & Treatment with $0.5 \mathrm{ml}$ root oil & Treatment with $2.5 \mathrm{ml}$ root oil \\
\hline Liver & $\begin{array}{l}\text { - Appeared as dark brown bilobed organ. } \\
\text { - Showed normal hexagonal lobular pattern. } \\
\text { - Also showed normal central vein [C], sinusoids } \\
\text { [S] and hepatic cells }[\mathrm{H}] \text {... Fig } 1 \mathrm{a} \text {. } \\
\text { - Sinusoids lined by fenestrated endothelium. } \\
\text { - Hepatocytes appeared as large polyhedral cells } \\
\text { with round nuclei dispersed chromatin and } \\
\text { prominent nucleoli. } \\
\text { - Cytoplasmic hepatocytes found granular and } \\
\text { deep eosinophilic. }\end{array}$ & $\begin{array}{l}\text { - General Architecture: found intact } \\
\text { - Central Vein: markedly dilated. } \\
\text { - Portal vein: almost found intact. } \\
\text { - Blood vessels: slightly Congested (+). } \\
\text { - Fatty changes: prominent }(++) \\
\text { - Necrosis: no changes were seen. } \\
\text { - Fibrosis: no changes were seen } \\
\text { - Inflammatory cells: few cells }(+) \text { seen }\end{array}$ & $\begin{array}{l}\text { - General Architecture: found intact } \\
\text { - } \text { Central Vein: markedly dilated .. Fig 1c. } \\
\text { - } \text { Portal vein: almost found intact. } \\
\text { - Blood vessels: Congested (+). } \\
\text { - Fatty changes: prominent }(++) \text {.. Fig 1b. } \\
\text { - } \text { Necrosis: not seen. } \\
\text { - Fibrosis: not seen } \\
\text { - Inflammatory cells: few cells }(+) \text { seen. }\end{array}$ \\
\hline Kidney & $\begin{array}{l}\text { - Appeared normally consisting of cortex and } \\
\text { medulla. } \\
\text { - Cortex showed normal glomeruli appeared as } \\
\text { dense rounded structure .. Fig } 2 a \text {. } \\
\text { - Vascular basement and glomerular basement } \\
\text { membranes have uniform thickness and } \\
\text { uninterrupted. } \\
\text { - Afferent and efferent arterioles were seen at } \\
\text { vascular pole of renal corpuscles. } \\
\text { - Proximal convoluted tubule (PCT) showed } \\
\text { simple cuboidal epithelium with brush border and } \\
\text { narrow lumen. } \\
\text { - Cytoplasm of PCT stained dark pink. } \\
\text { - Distal convoluted tubule (DCT) contains few } \\
\text { cuboidal cells with wide lumen. } \\
\text { - Cytoplasm of DCT stained light pink. } \\
\text { - Medulla consists of loop of Henle, collecting } \\
\text { tubules vasa recta and collecting duets. }\end{array}$ & $\begin{array}{l}\text { - Glomeruli: atrophic changes, hemolysis } \\
\text { and shrinkage. } \\
\text { - Basement membrane: no significant } \\
\text { changes } \\
\text { - Cellularity: normal. } \\
\text { - Inflammatory cells: not found } \\
\text { - Tubules: atrophic changes (+), hemolysis } \\
\text { - Neen. } \\
\text { - Becrosis: negligible } \\
\text { - Interstitium: edematous (+), fibrotic } \\
\text { changes not seen, inflammatory cells } \\
\text { (++) were found }\end{array}$ & $\begin{array}{l}\text { - Glomeruli: atrophic changes, hemolysis seen in } \\
\text { Fig } 2 \text { b. } \\
\text { - } \text { Basement membrane: normal. } \\
\text { - Cellularity: normal. } \\
\text { - Inflammatory cells: few cells (+) found. } \\
\text { - Tubules: atrophic changes (+), shedding of } \\
\text { epithelium, edema .. Fig 2b. desquamated cells } \\
\text { and hemorrhage also seen .. Fig } 2 c . \\
\text { - Necrosis: negligible } \\
\text { - Blood vessels: dilated, thickened and congested } \\
\text { - Interstitium: slightly edematous and few } \\
\text { inflammatory cells (+) found. }\end{array}$ \\
\hline
\end{tabular}




\section{Kidney changes in rats treated with a high dose of root oil}

Kidney tissues in the control group showed normal renal corpuscles (see Figure 2a) but some morphological and pathological changes occurred in the kidney tissues of albino rats (Group C) treated with a high dose of the root oil $(2.5 \mathrm{ml} / \mathrm{rat})$. In the glomerular region of the kidney, some atrophic changes and haemolysis were seen (Figure 2b) but cellularity and basement membrane were normal. No inflammatory cells were found. The tubular portion also showed atrophic changes, shedding of epithelium and oedema (Figure 2b). Furthermore, desquamated cells and haemorrhage (Figure 2c) were seen in the tubular region. The blood vessels became dilated, thickened and congested $(++)$, and a few inflammatory cells $(+)$ and slightly oedematous interstitial regions were seen.

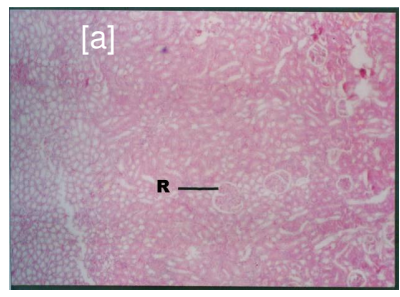

(a) Control kidney

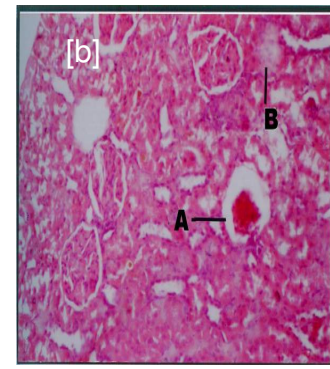

(b) Treated kidney

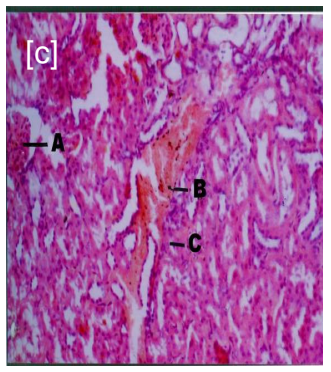

(c) Treated kidney
Figure 2: Sections (a) of rat kidney (Control) showing normal renal corpuscles (R); (b) showing atrophy of glomeruli and haemorrhage in glomeruli $(A)$, oedema in tubules (B); and (c) shrunken glomeruli (A), hemorrhage in tubules (B) and desquamated cells in tubules (C) following treatment of rats with Cedrus deodara root oil (2.5 $\mathrm{ml})$.
The findings are based on the morphological and pathological effects of the root oil on the animal tissues as indicated in Table 1. The features include prominent fatty changes, marked dilation of central vein, and congested blood vessels in liver tissues at both doses. The kidney tissues also showed marked changes at both doses such as hemolysis and shrinkage of glomeruli as well as the shedding of tubular epithelium and hemorrhage.

Thus Cedrus deodara root oil, at both low $(0.5 \mathrm{ml})$ and high $(2.5 \mathrm{ml})$ doses, produced some toxic changes in the different regions of liver and kidney tissues when compared with the untreated animals. However, at low dose, these changes are mild.

\section{DISCUSSION}

To the best of our knowledge, the pathologically effects of Cedrus deodara root oil on the liver and kidney tissues of albino (Wistar) rats are being reported for the first time in this study.

Marked dilation of the central vein and prominent fatty changes were observed in liver tissues at both low and high (Figure 1 and Table 1). Prominent morphological and pathological changes were also found in kidney tissues (Figure 2). One of the important compounds, himachalol, in the wood of $C$. deodara has been reported to exert antispasmodic activity on tissues such as the ileum, jejunum and bronchial muscles of guinea pigs and rabbits [3].

Significant changes have also been noticed [16] in the reproductive organs and tissues of rats, such as the luminal epithelium of uterus and uterine glands, following the administration of neem oil subcutaneously. In the present study, the liver and kidney of the rats experienced shedding of tubular epithelium of the glomeruli, congestion of blood vessels as well as atrophic changes in renal tubular epithelium, as shown earlier. The changes that took place in both liver and 
kidney tissues were probably due to the metabolic changes arising from the inhibition of enzymes when treated with root oil of different doses. On the other hand, no significant damage to organs were noticed following the oral administration of bitterless, odourless and colourless neem oil and groundnut oil in male and female rats up to three generations. These oils are generally accepted as safe for human consumption [17]. However, the present study indicates that cedar wood oil may not be safe in humans since it damaged the liver and kidney tissues of Wistar rats following oral administration.

The pathological and cytotoxic activities of AP9-Cd, a standardized lignan composition derived from Cedrus deodara, in human leukaemic Molt-4 and HL-60 cells, has also been noticed [8]. Similarly, the plant's lignan mixture has cytotoxic potential, in vitro, against human cancer lines from different tissues such as breast, cervix, colon, liver and prostate; it was also found to induce tumor regression in vivo, induction of intracellular DNA fragmentation and DNA cell cycle analysis [9]. No evidence can, however, be adduced from the present study that links the plant's lignan mixture to the root oil effects on the liver and kidney tissues of the animals.

\section{CONCLUSION}

Scientific analysis of these materials in relation to their pharmacological studies was not carried out in this study. In India, Pakistan and other countries, Colleges of Eastern Medicine commenced such studies before using these materials as drugs. The root oil used in the present work may be categorised under 'least toxic' group, according to the standard used by toxicologists. Thus, Cedrus deodara root oil may not be safe for human consumption, but this assertion requires further investigation.

\section{ACKNOWLEDGEMENT}

The authors gratefully acknowledge the assistance of Mr. Abdul Haseeb Khan, Chairman Brooke's Pharma (Pvt) Ltd., Karachi, Pakistan for providing the Cedrus deodara oil used in this study. We are also grateful to Prof. Dr. Syed Azhar Ahmed, Vice Chancellor, Baqai Medical University and Prof. Dr. Syed Fazal Hussain of Baqai Institute of Pharmaceutical Sciences for their technical support and cooperation. Mr. Arif Jawaid, Baqai Institute of Hematology, Baqai Medical University is thankfully acknowledged for assisting in putting this manuscript together.

\section{REFERENCES}

1. Baquar S.R. Medicinal and poisonous plants of Pakistan. Printas, Karachi, 1989; pp. 94-95.

2. Rehana P. Analysis of Cedrus deodara root oil and its pharmacokinetic and pharmacodynamic studes with reference to anti-ulcer and antifungal effects. Ph.D. Thesis Baqai. Med. Univ. 2006; pp. 76-79.

3. Kar K, Puri VN, Patnanik G.K, Sur RN, Dhawan BN, Kulshrestha DK, Rastogi RP. Spasmolytic constituents of Cedrus deodara: Pharmacological evaluation of Himachalol. J. Pharm. Sci. 1975; 64: 258-262.

4. Tandan CK., Singh R., Gupta S, Chandra S, Lal J. Subacute dermal toxicity study of Cedrus deodara wood essential oil. Indian. Vet. J. 1989; 66: 1088-1091.

5. Shinde UA, Kulkarni KR, Phadke AS, Nair AM, Mungantiwar AA, Dikshit VJ, Saraf MN. Mast cell stabilizing and lipoxygenase inhibitory activity of Cedrus deodara (Roxb) Loud wood oil. Indian. J. Exp. Biol. 1999; 37: 258 - 261.

6. Rawat $A$, Singh $A$, Singh $A B$, Gaur $S N$, Kumar $L$, Roy I., Ravidrun P. Clinical and immunologic evaluation of Cedrus deodara Pollen: a new allergen from India. Allergy. 2000; 55: 620626.

7. Dimri M, Sharma MC. Effects of sarcoptic manage and its control with oil of Cedrus deodara, Pangamia glabra, Jatropha curcas and benzyl benzoate both with and without ascorbic acid on growing sheep, assessment of weight gain, liver function, nutrient digestibility, wood production and meat quality. J. Vet. Med. A. Physiol. Pathol. Clin Med. 2004; 51: 79-84.

8. Shashi B, Jaswant $S$, Madhusudana RJ, Kumar $S A$, Nabi QG. A novel lignan composition from Cedrus deodara induces apoptosis and early nitric oxide generation in human leukemia 
Molt-4 and HL-60 cells. Nitric Oxide. 2006; 14: 72 - 78.

9. Singh SK, Shanmugavel M, Kampasi $H$., Singh $R$, Mondhe DM., Rao JM, Adwankar MK, Saxena, AK, Qazi GN. Chemically standardized isolates from Cedrus deodara stem wood having anticancer activity. Planta. Med. 2007; 73: $519-526$.

10. Yang $P$, Wang $Z$, Chen JW, Tian FL, Ge Lk. Influence of pine needles physiological properties on the $P A H$ accumulation. Huan Jing Ke Xue. 2008;29: 2018.

11. Khan N, Naheed S. Chemical investigation of Cedrus deodara stem-bark. I. Isolation and structure of branched chain fatty acid ethyl ester. J. Chem. Soc. Pak. 1988; 10: 63-65.

12. Khan $N$, Naheed $S$. Chemical investigation of Cedrus deodara stem bark. II. Isolation and identification of some sesquiterpene hydrocarbons. J. Chem. Soc. Pak. 1990; 12: 282-284.

13. Adinarayana $D$, Seshadri TR. Stem bark of Cedrus deodara. Isolation of new dihydroflavonol, deodarin. Tetrahedron. 1965; 21: 3727-3730.

14. Agarwal PK, Rastogi RP. Terpenoids from Cedrus deodara. Phytochemistry. 1981; 20: 13191321.

15. Bancroft JD, Stevens A. Theory and practice of histological techniques, 3rd Ed, Newyork, Churchill Livingstone 1990; pp. 281 - 282.

16. Tewari RK, Pathak S, Parkash AO. Biochemical and histological studies of reproductive organs in cyclic and ovariectomized rat supporting a non- hormonal action for neem oil. J. Ethnopharmacol. 1989; 25: 281 - 293.

17. Chinnasamy N, Harishankar N, Kumar PU, Rukmini C. Toxicological studies on debitterized neem oil (Azadirachta indica). Food Chem. Toxicol. 1993; 31: 297 - 301 